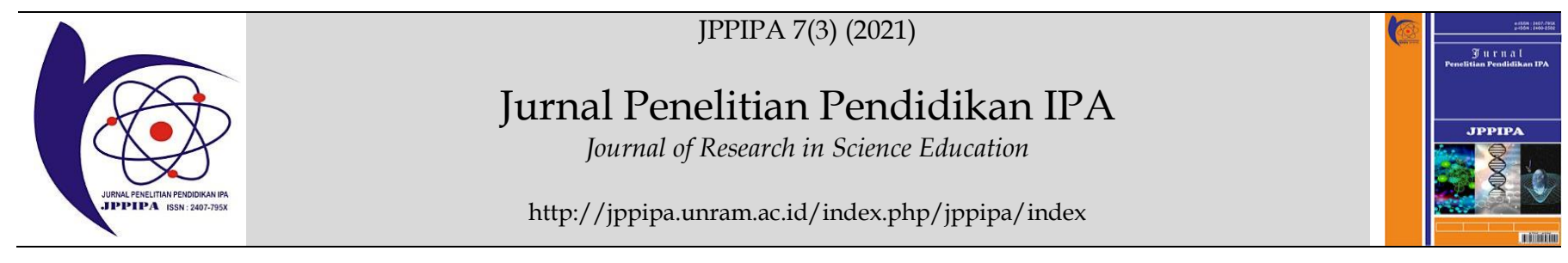

\title{
Analysis of the Nature of Science in Elementary School Science Curriculum and Its Empowerment in Student Book
}

\author{
Devi Septiani Putri ${ }^{1 *}$, Lungguh Puri Pramswari ${ }^{1}$, Sabila Idzni Suryana ${ }^{1}$, Ari Widodo² \\ ${ }^{1}$ Elementary Education, Graduate School, Indonesian University of Education, Bandung, Indonesia \\ ${ }^{2}$ Biology Education, Faculty of Mathematics and Natural Sciences Education, Indonesian University of Education, Bandung, Indonesia
}

DOI: $10.29303 /$ jppipa.v7i3.763

Article Info

Received: May 27th, 2021

Revised: July 15th, 2021

Accepted: July 25th, 2021

\begin{abstract}
The nature of Science or NOS is the knowledge that explains how science works and how scientists conduct research. The nature of science has aspects in the form of form and nature, namely aspects of the product, scientific attitude, process, subjective, tentative, empirical, Theory and Law, Social and Culture, Creativity, Scientific Method. It is important to convey aspects of the nature of science into the science curriculum and student books because they are a reference in the learning process so that learning objectives can be achieved properly. Submission of aspects of the nature of good science is to convey it correctly and explicitly. Based on the analysis and comparison results, it shows that aspects of the nature of science in the elementary school curriculum and its embodiment in student books are not explained explicitly, both in the curriculum and in student books. The results of the percentage value of the essence of science in the student curriculum have a value of $>80 \%$, namely product, subjective, creative aspects, and in the student's book, only product aspects have a percentage value of $>80 \%$. Meanwhile, other aspects have a low percentage value of $<80 \%$.
\end{abstract}

Keywords: The Nature of Science; Elementary School Science Curriculum; Student Books.

Citation: Putri, D.S., Pramswari, L.P., Suryana, S.I., \& Widodo, A. (2021). Analysis of the Nature of Science in Elementary School Science Curriculum and Its Empowerment in Student Book. Jurnal Penelitian Pendidikan IPA, 7(3), 488-495. doi:https://doi.org/10.29303/jppipa.v7i3.763

\section{Introduction}

The nature of Science or Nature of Science (NOS) is the knowledge that explains how science works and how scientists conduct research (Listiani \& Kusuma, 2017). NOS can also be interpreted as the epistemology of science, where science is a way to acquire knowledge or values and beliefs inherent in scientific knowledge or science development (Tursinawati \& Widodo, 2019). Learning the nature of science is very important for both teachers and students because it can provide benefits, such as having an important and detailed background on how science and scientists work and how scientific knowledge is created, validated, and influenced; have an accurate view of what science is, the types of questions that science can answer, how science differs from other disciplines, the strengths and limitations of scientific knowledge; and can recognize and reject scientific product claims when encountered in everyday life (Adi \& Widodo, 2018).

The nature of science has aspects in the form of form and nature. The form of the nature of science, consisting of (a) Products, phenomena, behavior, characteristics that are packaged into a theory, concept, law, and principle, (b) The process of acquiring knowledge which is none other than the scientific method (c) Scientific Attitude, instilling attitudes in scientists when carrying out the scientific method process and science learning process (Tursinawati, 2016). While the nature of science consists of (a) Empirical Based, scientific knowledge based on data or evidence derived from observations through the five

\footnotetext{
*Email: deviseptianiputri1908@gmail.com
} 
senses or experiments, (b) Tentative, scientific knowledge is something that can be perfected through new observations and with reinterpretations that exists because it is not an absolute truth without error, (c) Theories and Laws in the form of laws represent relationships, observations, perceptions of natural phenomena accompanied by mathematical formulas. Meanwhile, the theory explains natural phenomena and the mechanism of the relationship between natural phenomena. Furthermore, (d) Social and Cultural, the science which is the result of human efforts, so that the process is influenced by society and culture, (e) Creativity, scientific knowledge is created from human imagination, creativity, and logical reasoning so that the science continues to develop. In addition, creative planning, observations, and conclusions are created, (f) the Scientific Method, it is explained that there is no definite and universal scientific method, every scientist who will conduct research is given the freedom to determine the method he will use, as long as it can be justified answer, (g) Subjective, Science is unavoidable in science which can be influenced by factors, such as personal values, beliefs, self agenda, and previous experiences. In addition, research will also be influenced by how a scientist does his job (Adi \& Widodo, 2018).

Understanding the nature of science can provide a detailed background on how science and scientists work, how scientific knowledge is created, validated, and influenced. Understanding the nature of science is important to understand. Here are five arguments regarding the importance of understanding the nature of science, namely: 1) Utilitarian, for understanding science and managing technological objects and processes in everyday life, 2) Democratic, for information deciding socioscientific issues, 3) Cultural, to appreciate the value of science as part of contemporary culture, 4) Moral, to help develop an understanding of the norms of the scientific community that embodies moral commitments regarding general values to society, 5) Science learning, to facilitate learning science subject matter (Rahayu \& Widodo, 2019).

Science education is one of the tools to achieve an educational goal. This science education is directed to inquiry to help students deepen their understanding of the natural surroundings. This has implications for learning in schools where science learning in schools must contain the nature of science in it (Ali et al., 2018). The nature of science is the basis for studying science because the nature of science has many influences on science education. With the nature of science, students are expected to be able to think scientifically and wisely in addressing a problem (Annisa \& Listiani, 2017). Science learning in schools starting from planning learning, implementing learning, to evaluating learning, must reflect the nature of science, including in the science curriculum (Ali et al., 2018). Science learning must be designed properly so that it can affect aspects of student attitudes that can arouse students' curiosity, then proceed in solving a problem that arises using the right learning model so that it can produce a product in the form of facts, principles, theories and laws that are appropriate and can also be realized in everyday life (Dewi et al., 2017). By integrating the nature of science in the curriculum, it is hoped that it can help students become citizens who have scientific literacy to solve complex science and technology problems (Khery et al., 2018).

One of the characteristics of someone who has scientific literacy is someone who understands the nature of Science (Amilia et al., 2017). Therefore, it is important to convey aspects of the nature of science into the science curriculum. Submission of aspects of the nature of good science is to convey it correctly and explicitly. This is marked by the delivery of the nature of science directly, firmly, explicitly and does not take long to understand the idea. In addition to the curriculum, the nature of science also needs to be conveyed in textbooks so that it is relevant to the curriculum that has been prepared. Good quality books are books that are relevant and can support the process of implementing the curriculum because textbooks and curriculum are related to each other (Jannah et al., 2019).

Textbooks are a very important component of education in the learning process. The teacher uses at least one textbook in the learning process. The textbooks used should be in accordance with the demands and needs contained in the curriculum (Sesrita, 2020). Science textbooks used in the learning process must construct the concepts studied in accordance with the nature of existing science. In the implementation of learning, student books are mostly used as learning resources for students. Students' books are expected to contain aspects of the nature of science so that the learning process can be carried out properly.

Science learning has unique characteristics compared to other subject matter. Therefore, in science learning, it is necessary to meet the characteristics of science, namely the nature of science in the learning process activities (Sayekti et al., 2019). However, based on TIMSS (2015), science education in Indonesia is still very far behind other countries with an average science score of 397 points and ranks 45 out of 48 who took part in the survey (Adi \& Widodo, 2018). So based on these problems, to determine the suitability of the science curriculum with the nature of science and its embodiment in student books. 


\section{Method}

In this study, a document analysis method with a descriptive quantitative approach was used which aims to reveal something as it is. This study also conducts comparisons that aim to compare the existence of one or more variables in two or more different samples or at different times (Satryawan, 2016). This was done to find out the differences in the nature of Science between Indonesia and other countries (Japan, Singapore, and Turkey).

The steps are taken in the research this as follows: (a) The preparation stage, such as reviewing the literature on the NOS aspects and determining the NOS aspects used, namely from the aspect of form, including products, processes, attitudes, and from the nature aspect, in the form of empirical, tentative, subjective, creative, theoretical and legal, social and cultural, and scientific method; (b) The analysis stage, by analyzing the basic competencies and content in the curriculum as well as their embodiment in student books, was carried out by three researchers and correlated with each other. Based on the results of the agreement of the three researchers, the minimum value limit in the data analysis process was $80 \%$; (c) The comparison stage is like comparing curriculum and content in Indonesia with other countries (Japan, Singapore, and Turkey).

The final stage, processing the research data by calculating the percentage in each NOS and providing an explanation of the results of the analysis in each NOS.

\section{Result and Discussion}

It is important to convey aspects of the nature of science into the science curriculum, one of which is in basic competencies which become a reference in the learning process. Submission of aspects of the nature of good science is to convey it correctly and explicitly (Jannah et al., 2019). If designing a lesson plan is wrong, it will have an impact on the implementation of the learning itself (Hidayah et al., 2016). So, it is necessary to analyze the nature of science in the basic competencies of elementary school science. The results of the analysis show that aspects of the nature of science have not been explicitly conveyed in the basic competencies, both in terms of form and aspects of nature.

Table 1. Percentage of the Nature of Science in curriculum

\begin{tabular}{llll}
\hline \multirow{2}{*}{ Classes } & Form & & \\
\cline { 2 - 4 } & Product (\%) & Attitude (\%) & Process $(\%)$ \\
\hline 1 & 80.0 & 0.0 & 0.0 \\
2 & 100 & 0.0 & 50.0 \\
3 & 80.0 & 0.0 & 0.0 \\
4 & 100 & 0.0 & 87.5 \\
5 & 100 & 0.0 & 55.5 \\
6 & 88.8 & 0.0 & 44.4 \\
Average & 91.5 & 0.0 & 39.6 \\
\hline
\end{tabular}

Based on the results of the analysis of the curriculum documents in Table 1 regarding the nature of science, the product aspect has the highest percentage, which is $91.5 \%$. In basic competence, the product aspect has been explained explicitly, wherein every material studied by students must contain knowledge that is a product of scientists' observations.

Meanwhile, the lowest aspect is attitude, which is $0.0 \%$. In the aspect of attitude, it has a low percentage because this aspect is not explicitly explained in the Basic Science Competencies of Elementary Schools regarding attitudes that are carried out to acquire, develop, and apply knowledge. This is also evidenced by Tursinawati's research (2010) that students' understanding of the science aspect as an attitude is in the lowest category compared to other aspects. This can happen because teachers do not understand all aspects of the nature of science. Moreover, these aspects are explained in basic competencies (Tursinawati, 2016).

Based on the results of the analysis of the curriculum documents in Table 2 regarding the nature of science, the creative aspect has the highest percentage compared to other characteristics, which is $93.0 \%$. This aspect is included in the high category because it has a percentage value of $>80 \%$. This also applies to the subjective aspect with a value of $87.9 \%$. This is because in each point 4 , basic competence, which is a derivative of the core competence point 4 , focuses on developing student skills. Therefore, most of the creative aspects are explained explicitly in the basic competence point 4 . This is what makes the creative aspects have the highest percentage value.

Table 2. Percentage of Nature of Science in Curriculum

\begin{tabular}{llllllll}
\hline \multirow{3}{*}{ Classes } & \multicolumn{2}{l}{ Characteristic } & & & \\
\cline { 2 - 7 } & Empirical (\%) & Tentative (\%) Subjective (\%) & $\begin{array}{l}\text { Theory and law } \\
(\%)\end{array}$ & Creativity (\%) & $\begin{array}{l}\text { Social and } \\
\text { Cultural (\%) }\end{array}$ & $\begin{array}{l}\text { Scientific Method } \\
(\%)\end{array}$ \\
\hline 1 & 60.0 & 60.0 & 100 & 20.0 & 80.0 & 40.0 & 40.0 \\
2 & 50.0 & 100 & 100 & 100 & 100 & 100 & 100 \\
3 & 20.0 & 20.0 & 40.0 & 80.0 & 100 & 40.0 & 80.0 \\
\hline
\end{tabular}




\begin{tabular}{llllllll}
\hline \multirow{2}{*}{ Classes } & \multicolumn{2}{l}{ Characteristic } & & & \\
\cline { 2 - 7 } & Empirical (\%) & Tentative (\%) Subjective $(\%)$ & $\begin{array}{l}\text { Theory and law } \\
(\%)\end{array}$ & Creativity $(\%)$ & $\begin{array}{l}\text { Social and } \\
\text { Cultural }(\%)\end{array}$ & $\begin{array}{l}\text { Scientific Method } \\
(\%)\end{array}$ \\
\hline 4 & 62.5 & 12.5 & 87.5 & 87.5 & 100 & 12.5 & 75.0 \\
5 & 33.3 & 44.4 & 100 & 88.8 & 100 & 11.1 & 33.3 \\
6 & 33.3 & 22.2 & 100 & 44.4 & 77.7 & 11.1 & 33.3 \\
Average & 43.2 & 43.2 & 87.9 & 70.2 & 93.0 & 35.8 & 60.3 \\
\hline
\end{tabular}

The aspect of creativity is also closely related to the subjective aspect because the skills of each student are different by following each subject, such as personal values, beliefs, self agendas, and previous experiences (Jumanto \& Widodo, 2018). For example, the Basic Competence in Class 5, which is 4.3 Presenting works on the concept of digestive organs and functions in animals or humans, the creativity aspect in these basic competencies is in the form of presenting a workshop on the digestive organs and their functions in which students are required to think creatively in producing the work. The work produced will also vary from each student, depending on the student's imagination. This is reinforced by Piaget's theory, that the stages of elementary school students are in the concrete operational stage where at this stage they cannot think abstractly. His ability to think a little abstractly must always be preceded by concrete experience (Ibda, 2015). Thus, each student has different thoughts based on their respective experiences. This is also related to the students' creativity because, according to Clarkl Monstakis, creativity is an experience in expressing and actualizing individual identity in an integrated form between the relationship between oneself, nature, and others (Bahrudin et al., 2018).

By not explicitly explaining the basic competencies, it will have an effect on students' low understanding of science itself because basic competencies are included in the learning planning process, which becomes a reference when the learning process takes place. This can be proven by a review conducted by TIMSS (Trends in International Mathematics and Science Study), showing that the average achievement of students in Indonesia in the field of science is below the international average. This can happen because of the lack of application of the nature of science in planning and managing science learning (Rusmana, 2018).

In the social and cultural aspects, it has a low percentage value, which is $35.8 \%$. This aspect is not explicitly explained in the Basic Science Competence of Elementary Schools. This can happen because there is no knowledge that is influenced by society and culture. Like Basic Competence 3.1 above, it is not clearly explained the relationship between the material and the influence of society and culture. This also applies to the empirical and tentative aspects.
According to Pannen, teaching materials are materials or subject matter that are systematically arranged, which are used by teachers and students in the learning process. In 1994, Rowntree grouped four teaching materials based on their nature, including printed teaching materials. Printed teaching materials are a number of materials prepared on paper, which can function for learning purposes or delivering information (Nasution et al., 2017). One example of printed teaching materials, namely student books. Student books are references or references that can be used to explore knowledge so that students have a broad understanding to optimize their abilities (Sriwindayani et al., 2016).

Student books as teaching materials are very important for teachers and students in the learning process. With student books, teachers can save time in teaching, change the teacher's role from a teacher to a facilitator, improve the learning process, become more effective and efficient. Likewise, the role of student books for students is very important because it can help students learn independently (Nasution et al., 2017). By knowing the importance of the role of student books as teaching materials, we conducted an analysis of the nature of science in student books to evaluate the student books to be in accordance with educational goals and the applicable curriculum (Jannah et al., 2019)

Table 3. Percentage of the Nature of Science in Student Books

\begin{tabular}{llll}
\hline \multirow{2}{*}{ Classes } & Form & & \\
\cline { 2 - 4 } & Product $(\%)$ & Attitude $(\%)$ & Process $(\%)$ \\
\hline 1 & 100 & 28.5 & 14.2 \\
2 & 87.5 & 0.0 & 12.5 \\
3 & 100 & 75.0 & 80 \\
4 & 100 & 88.8 & 100 \\
5 & 100 & 55.5 & 100 \\
6 & 88.5 & 55.5 & 88.8 \\
Average & 96 & 50.5 & 65.9 \\
\hline
\end{tabular}

Based on the results of the analysis of student book documents in Table 3 above on the existence of The Essence of Science, the product aspect has the highest percentage, which is $96 \%$. Meanwhile, aspects of attitude and process have a low percentage value, namely $50.5 \%$ and $65.9 \%$, which is still far from the minimum value of $80 \%$. In the student book, each 
material to be studied must contain products in the form of theories and concepts that will be studied. For example, pages 44-45 explain the advantages and privileges of snails. It expresses new knowledge for students that is a product of.

It has a low percentage in terms of attitudes and processes because in each material studied, and there is no expected scientific attitude and process in the textbook. As in pages $44-45$ above, there are no activities that require students to produce new knowledge or attitudes to apply and acquire knowledge.

Table 4. Percentage of Nature of Science in Student Books

\begin{tabular}{llllllll}
\hline \multirow{2}{*}{ Classes } & \multicolumn{2}{l}{ Characteristic } & & \\
\cline { 2 - 7 } & Empirical (\%) Tentative (\%) & Subjective $(\%)$ & $\begin{array}{l}\text { Theory and law } \\
(\%)\end{array}$ & Creativity (\%) & $\begin{array}{l}\text { Social and } \\
\text { Cultural }(\%)\end{array}$ & $\begin{array}{l}\text { Scientific Method } \\
(\%)\end{array}$ \\
\hline 1 & 71.4 & 57.1 & 85.7 & 28.5 & 42.8 & 14.2 & 28.5 \\
2 & 12.5 & 37.5 & 25.0 & 0.0 & 12.5 & 0.0 & 37.5 \\
3 & 80 & 0.0 & 80.0 & 75.0 & 40.0 & 0.0 & 80.0 \\
4 & 100 & 0.0 & 77.7 & 77.7 & 100 & 0.0 & 77.7 \\
5 & 55.5 & 22.2 & 11.1 & 44.4 & 44.4 & 0.0 & 77.7 \\
6 & 88.8 & 11.1 & 0.0 & 22.2 & 22.2 & 0.0 & 88.8 \\
Rata-rata & 68.0 & 21.3 & 46.6 & 3.32 & 43.6 & 2.4 & 65.0 \\
\hline
\end{tabular}

Based on the results of the analysis of student book documents in Table 4 above regarding the nature of science, the empirical aspect has the highest percentage value compared to other aspects. However, the empirical aspects and other aspects are still categorized as low aspects. This is because the empirical and other aspects have a percentage value below the minimum value of $<80 \%$. The aspects of science above have a percentage value of $<80 \%$ because the material in the textbook is not fully contained or has the nature of science above.

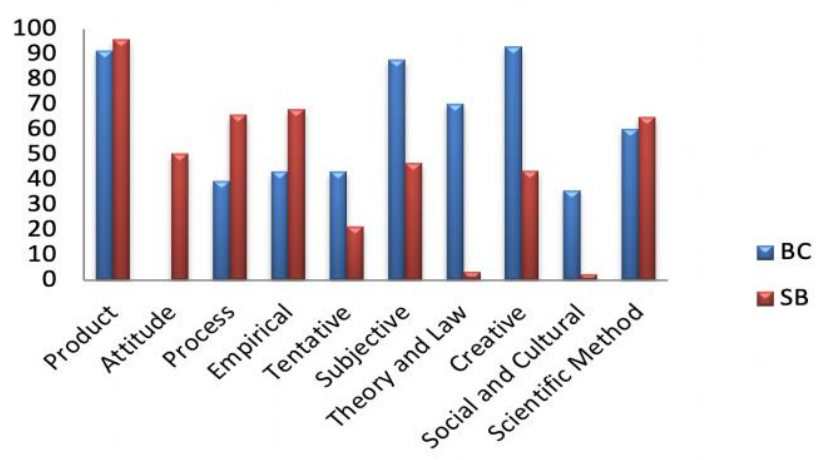

Figure 1. Comparison Diagram of the Nature of Science in Basic Competencies and Student Books

Based on the results of the analysis of the nature of science in the curriculum and student books, the aspect that has a high percentage value with a value of $>80 \%$ is the product aspect. The difference in the percentage value is not too high in the product aspect, which is $4.5 \%$ between the curriculum and student books. In the aspect of the scientific method, the difference in the presentation value is not too high, which is $4.7 \%$. However, this aspect is included in the low category with a percentage value of $<80 \%$. The difference in the percentage value that is not too far proves that the implementation of the curriculum in the student book is quite appropriate.

The results of the analysis of the nature of science in the curriculum and student books on aspects of attitude and theory and law have a fairly high percentage difference. In the aspect of attitude, it has a difference in the percentage value of $50.5 \%$, and in the theoretical and legal aspects, it has a difference in the percentage value of $66.8 \%$. This proves that there is a discrepancy between the curriculum and student books.

According to Olson, the nature of science is rarely the hope of students in carrying out the learning process because the nature of science is only found in additional teaching materials and curriculum, but it does not bring out the nature of science consistently. In addition, almost all documents analyzed regarding the standard of the nature of science do not provide conceptual or pedagogical support so that the nature of science can be interpreted accurately or translated into meanings derived from student experience (Tursinawati \& Widodo, 2019). This causes there to be differences in the percentage of aspects of the nature of science in the curriculum and student books.

Table 5. Comparison of the Nature of Science in Curriculum in Indonesia with Other Countries (Japan, Singapore, Turkey)

\begin{tabular}{lcll}
\hline Countries & Form & & \\
\cline { 2 - 4 } & Product $(\%)$ & Attitude $(\%)$ & Process (\%) \\
\hline Indonesia & 91.5 & 0.0 & 39.6 \\
Japan & 100 & 33.3 & 100 \\
Singapore & 100 & 100 & 95.0 \\
Turkey & 100 & 92.8 & 96.4 \\
\hline
\end{tabular}


From the analysis of the percentage values in Table 5 regarding the nature of science from the various countries above, the percentage value between each country does not have too much difference in the product aspect. This implies that the nature of science in the product aspect of the curriculum in Indonesia is good. Meanwhile, in the aspect of process and attitude, Indonesia has the smallest percentage compared to other countries. This is because many forms of the nature of science are not explicitly explained in the curriculum, and there is a discrepancy between the curriculum and student books in the application of the nature of science. While in other countries (Japan, Singapore, and Turkey), aspects of attitudes and processes are explained explicitly in the curriculum.

Table 6. Comparison of the Nature of Science in Curriculum in Indonesia with Other Countries (Japan, Singapore, Turkey)

\begin{tabular}{llllllll}
\hline \multirow{2}{*}{ Countries } & Characteristic & & & & \\
\cline { 2 - 7 } & Empirical (\%) & Tentative (\%) & Subjective (\%) & $\begin{array}{l}\text { Theory and law } \\
(\%)\end{array}$ & Creativity (\%) & $\begin{array}{l}\text { Social and } \\
\text { Cultural (\%) }\end{array}$ & $\begin{array}{l}\text { Scienti-fic } \\
\text { Method (\%) }\end{array}$ \\
\hline Indonesia & 43.2 & 43.2 & 87.9 & 70.2 & 93.0 & 35.8 & 60.3 \\
Japan & 50.0 & 83.3 & 100 & 33.3 & 50.0 & 66.7 & 83.3 \\
Singapore & 75.5 & 0.0 & 24.4 & 100 & 100 & 0.0 & 70.5 \\
Turkey & 100 & 89.2 & 100 & 82.0 & 96.4 & 57.0 & 100 \\
\hline
\end{tabular}

From the analysis of the percentages from various countries above, most of the science learning is in accordance with the nature of science, both products, processes, and attitudes. For the manifestation of the nature of science in the form of products, processes, and attitudes in Indonesia, it has the smallest percentage. This is because many forms of the nature of science are not explicitly explained in the curriculum. Theree is a mismatch between the curriculum and student books inapplyingf the nature of science. Meanwhile, in other countries, it is very clearly explained in the curriculum. This also applies to the nature of science, where not all aspects are included in the elementary school curriculum in Indonesia, which is proven by the percentage in the nature of science which still tends to be small.

In addition to the results of the comparative analysis of the nature of science in the curriculum in Indonesia with other countries (Japan, Singapore, Turkey), it is also evidenced by the results of the 2018 PISA (Program for International Student Assessment) score, Indonesia's scientific ability is ranked 70 out of 78 with a score of 396. Meanwhile, Japan, Singapore, and Turkey rank far above Indonesia, where Singapore is in 2nd place with a score of 551, Japan is in 5th place with a score of 529, and Turkey is ranked 40th with a score of 468 .

This is also evidenced by McComas, who states that the nature of science needs to be taught by teachers, but often gets less attention. In fact, the nature of science is important because it can provide background to students on how science and scientists work and how scientific knowledge can be created, validated, and also influenced. The nature of science contained in education is not to indoctrinate but to show the students' reasons for accepting a certain situation (Widodo, Adi, \& Imran, 2019).

The results of the analysis that have been carried out, the 2013 curriculum in science subjects and student books in elementary schools have brought up aspects of the nature of science, but the proportion of the emergence of aspects of the nature of science presented is not fully balanced and is not explained explicitly. So, special attention is needed so that the ten aspects of the nature of science can be raised and there is an equalization of aspects of the nature of science that are balanced and explained explicitly, both in the curriculum and in student books. It aims to provide a complete picture of the nature of science for students. Thus, it is hoped that students can be more motivated to have a desire to study science, especially the nature of science which in the future is able to advance science and technology and be able to solve problems in the digital era based on super-sophisticated knowledge and technology with the help of science itself. As is the case in Singapore, Japan, and Turkey, where the nature of science in the country's curriculum is explained explicitly and balanced so that students have the desire to study science itself, especially the nature of science that is able to advance science and technology and be able to solve problems in the digital era. Based on super-sophisticated knowledge and technology with the help of science itself.

\section{Conclusion}

Based on the results of research on the analysis of science in the elementary school science curriculum and its embodiment in student books, it can be concluded that in general, the 2013 curriculum in science subjects and elementary school student books 
has brought up aspects of the nature of science. However, there are still some aspects that have not been raised, such as aspects of attitude, process, empirical, tentative, theory and law, social and culture, as well as scientific methods that are not explicitly raised in the curriculum. Meanwhile, aspects of attitude, process, empirical, tentative, subjective, theory and law, creativity, social and culture, and the scientific method in the student book are not raised explicitly. Each aspect of the nature of science has a different proportion of appearances in the 2013 curriculum and elementary school student books. This proves that there is a discrepancy between the curriculum and student books. In addition, based on the results of the comparative analysis of the nature of Science, Indonesia has the smallest percentage value compared to other countries (Singapore, Japan, Turkey).

\section{Acknowledgment}

With the completion of this research, we would like to thank the teachers, lecturers, and friends at the Indonesian Education University who have provided motivation, assistance, and direction in carrying out this research, so that it can be carried out properly.

\section{References}

Adi, Y. K., \& Widodo, A. (2018). Pemahaman Hakikat Sains Pada Guru Dan Siswa Sekolah Dasar. Edukasi Journal, 10(1), 55-72. https://doi.org/10.31603/edukasi.v10i1.1831 [Indonesian]

Ali, L. U., Dk, E., Tarbiyah, F., \& Agama, I. (2013). Pengelolaan Pembelajaran IPA Ditinjau Dari Hakikat Sains Pada SMP Di Kabupaten Lombok Timur. e-Journal Program Pascasarjana Universitas Pendidikan Ganesha Program Studi IPA. 3(1)), 103112. Retrieved from: https://ejournalpasca.undiksha.ac.id/index.php/jurnal_ipa/articl e/view/750 [Indonesian]

Amilia, R., Rahayu, S., \& Yulianti, E. (2017). Pentingnya Mengeksplisitkan Nature Of Science ( NOS ) dan Berpikir Kritis pada Bahan Ajar IPA Topik Suhu dan Kalor Untuk Siswa SMP. Prosiding Seminar Nasional Pembelajaran IPA Ke-2, (October). [Indonesian]

Annisa, M., \& Listiani, L. (2017). Pemahaman AspekAspek dalam Hakikat Sains (Nature of Science) oleh Guru Sekolah Dasar di Wilayah 4P (Pedalaman, Perbatasan, Perkotaan, dan Pesisir). Jurnal Ilmiah Sekolah Dasar, 1(4), 241-246. doi:http://dx.doi.org/10.23887/jisd.v1i4.12709. [Indonesian]
Bahrudin, B., Hidayat, S., \& Hendrayana, A. (2018). Penerapan Model Pembelajaran Berbasis Proyek Dengan Memanfaatkan Tik Untuk Meningkatkan Kreativitas Dan Hasil Belajar Siswa Sekolah Dasar. Jurnal Teknologi Pendidikan Dan Pembelajaran, 5(2), 131-139. Retrieved from: https://jurnal.untirta.ac.id/index.php/JTPPm/ar ticle/view/7481 [Indonesian]

Dewi, V. P., Doyan, A., \& Soeprianto, H. (2017). Pengaruh Model Penemuan Terbimbing Terhadap Keterampilan Proses Sains Ditinjau Dari Sikap Ilmiah Pada Pembelajaran IPA. Jurnal Penelitian Pendidikan IPA, 3(1). https://doi.org/10.29303/jppipa.v3i1.102 [Indonesian]

Hidayah, Ulfah., Putrayasa, Ida Bagus., Martha, I. N. (2016). Konsistensi Kompetensi Inti (Ki), Kompetensi Dasar $(\mathrm{Kd})$, Dan Indikator Pada Evaluasi Guru Dalam Pembelajaran Eksposisi Berdasarkan Kurikulum 2013 Siswa Kelas X Man Patas. E-Journal Pendidikan Bahasa Dan Sastra Indonesia Universitas Pendidikan Ganesha, 5(3). doi: http://dx.doi.org/10.23887/ijpbs.v5i3.8766 [Indonesian]

Ibda, F. (2015). Perkembangan Kognitif: Teori Jean Piaget. Intelektualita, 3(1), 242904. Retrieved from: https://jurnal.arraniry.ac.id/index.php/intel/article/view/197 [Indonesian]

Jannah, N., Suyana, I., \& Novia, H. (2019). Analisis Hakikat Sains (Nature of Science) dalam Buku Teks Fisika SMA Kelas X di Kota Bandung. Prosiding Seminar Nasional Fisika, 0, 160-166. Retrieved from: http:// proceedings.upi.edu/index.php/sinafi/ar ticle/view/582 [Indonesian]

Jumanto, J., \& Widodo, A. (2018). Pemahaman Hakikat Sains Oleh Siswa Dan Guru Sd Di Kota Surakarta. Jurnal Komunikasi Pendidikan, 2(1), 20. https://doi.org/10.32585/jkp.v2i1.61 [Indonesian]

Khery, Y., Nufida, B. A., Rahayu, S., \& Budiasih, E. (2018). Karakteristik Nature of Science ( NOS ) dan Penerapan Teknologi Mobile dalam Pembelajaran Kimia. Prosiding Seminar Nasional Kimia Dan Pembelajarannya (SNKP), (November). [Indonesian]

Listiani, \& Kusuma, A. E. (2017). View of Nature of Science (VNOS) Form B: Sebuah Instrumen untuk Mengetahui Pemahaman Konsep Hakikat Sains Calon Guru di Universitas Borneo Tarakan. Jurnal Pendidikan Biologi Indoneisa, 3(1), 45-54. [Indonesian]

Nasution, S., Afrianto, H., Nurfadillah, S. \& J., Nim, N., Sadjati, I. M., Agent, S. G., ... Aceh, D. (2017). 
Berbagai Pendekatan dalam Proses Belajar dan Mengajar. Jurnal Pendidikan, 3(1), 1-62. https://doi.org/10.1017/CBO9781107415324.004 [Indonesian]

Rahayu, A. H., \& Widodo, A. (2019). Understanding of Nature of Science Pre-Service Students and Elementary School Teachers in the Digital Age. Jurnal Ilmiah Pendidikan MIPA, 9(2), 161-172. https://doi.org/10.30998/formatif.v9i2.3251 [Indonesian]

Rusmana, A. N. (2018). Aplikasi Hakikat Sains dalam Perencanaan dan Pengelolaan Pembelajaran IPA di Indonesia: Sebuah Kajian Literatur. (March 2016). [Indonesian]

Satryawan, E. (2016). Studi Komparatif Prestasi Belajar Mahasiswa Antara Penerima Beasiswa Dengan Tidak Penerima Beasiswa Di Fakultas Ekonomi Dan Bisnis Universitas Pendidikan Ganesha Angkatan 2011. Jurnal Program Studi Pendidikan Ekonomi (JPPE), $\quad 7(2) . \quad$ doi: http://dx.doi.org/10.23887/ijpe.v7i2.7683 [Indonesian]

Sayekti, I. C., Rini, I. F., \& Hardiyansyah, F. (2019). Analisis Hakikat Ipa Pada Buku Siswa Kelas Iv Sub Tema I Tema 3 Kurikulum 2013. Profesi Pendidikan Dasar, 6(2), 129-144. https://doi.org/10.23917/ppd.v1i2.9256 [Indonesian]

Sesrita, A. (2020). Pengaruh Profesionalisme Guru Terhadap Motivasi Belajar Siswa SD Negeri. SITTAH: Journal of Primary Education, 1(2), 139148. doi:

https://doi.org/10.30762/sittah.v1i2.2486

[Indonesian]

Sriwindayani, K. E., Agung, A. A. G., \& Tastra, I. D. K. (2016). Analisis Buku Siswa Pada Kurikulum 2013 Ditinjau Dari Aspek Desain Pesan Pembelajaran Di Kelas V Sekolah Dasar Negeri 3 Banjar Jawa Di Singaraja. Jurnal EDUTECH Undiksha, 5(2). doi: http://dx.doi.org/10.23887/jeu.v4i2.7719

[Indonesian]

Tursinawati, T., \& Widodo, A. (2019). Pemahaman Nature of Science (NoS) Di Era Digital: Perspektif Dari Mahasiswa PGSD. Jurnal IPA \& Pembelajaran IPA, 3(1), 1-9. https://doi.org/10.24815/jipi.v3i1.13294 [Indonesian]

Tursinawati. (2016). Penguasaan Konsep Hakikat Sains Dalam Pelaksanaan Percobaan Pada Pembelajaran Ipa Di Sdn Kota Banda Aceh. Jurnal Pesona Dasar, 2(4), 72-84. https://doi.org/10.24815/pear.v7i2.14753 [Indonesian]

Widodo, A., Adi, Y. K., \& Imran, M. E. (2019). Pemahaman Nature of Science ( NOS ) oleh siswa dan guru sekolah dasar. Jurnal Inovasi Pendidikan IPA, 5(2), 237-247. Retrieved from https://journal.uny.ac.id/index.php/jipi/article/ view/27294 [Indonesian] 